\title{
Could vagus nerve stimulation target hippocampal hyperactivity to improve cognition in schizophrenia?
}

\author{
Jason Smucny ${ }^{1,2,3}{ }^{*}$, Adrienne Visani ${ }^{3}$ and Jason R. Tregellas ${ }^{1,2,3}$ \\ ${ }^{1}$ Neuroscience Program, University of Colorado Anschutz Medical Campus, Aurora, CO, USA \\ ${ }^{2}$ Research Service, Denver Veterans Affairs Medical Center, Denver, CO, USA \\ ${ }^{3}$ Department of Psychiatry, University of Colorado Anschutz Medical Campus, Aurora, CO, USA \\ *Correspondence: jason.smucny@ucdenver.edu \\ Edited by: \\ Joaquim Radua, King's College London, UK \\ Reviewed by: \\ Daniel J. Lodge, University of Texas Health Science Center in San Antonio, USA \\ Diego Redolar-Ripoll, Open University of Catalonia (UOC), Spain
}

Keywords: vagus nerve stimulation, schizophrenia patients, hippocampus, cognition, acetylcholine

Despite the fact that cognitive function is the best predictor of functional outcome and quality of life in schizophrenia (1), cognitive symptoms remain poorly treated in the illness. A myriad of cognitive domains are affected, including selective and sustained attention, working memory, episodic memory, processing speed, executive function, and social cognition (2). Patients consequently suffer from high unemployment rates $(80 \%)$ and most are unable to live independently (30\%) (3). Clearly, new treatments are needed.

One strategy for developing new interventions for these symptoms is to focus on treatments that may target biological indicators ("biomarkers") of cognitive dysfunction. Recently, our laboratory found that resting-state hyperactivity of the hippocampus (as examined by functional magnetic resonance imaging) was strongly predictive of poor cognition in schizophrenia patients (4). This finding, along with previous studies that have demonstrated increased hippocampal blood flow (5), blood volume $(6,7)$, and hyperactivity during sensory processing $(8,9)$ in the disease suggests that hippocampal hyperactivity may be a biomarker for cognitive dysfunction in the illness (10). Loss of inhibitory signaling in the hippocampus is also hypothesized to play a role in sensory filtering deficits in schizophrenia (11), one of the most prominent electrophysiological features of the disease. This loss is thought to be conveyed through reduced nicotinic $(12,13)$ and/or GABAergic (14) signaling. It follows that interventions that reduce hippocampal hyperactivity may have therapeutic benefit in schizophrenia.
First developed in the 1980s for epilepsy, vagus nerve stimulation (VNS) may be a promising method for targeting hippocampal hyperactivity and improving cognition in schizophrenia. The vagus nerve (VN) is the longest cranial nerve, extending from the brain to the abdominal cavity. Although the $\mathrm{VN}$ is traditionally thought to primarily mediate central nervous system control of parasympathetic function, in actuality the VN consists of $80 \%$ afferent signals (from external organs to the brain) and 20\% efferent signals (from the brain to organs) (15). VNS is most commonly achieved by surgical implantation of a stimulating, current-carrying wire around the nerve in the neck (16). The wire is intermittently stimulated by a battery-operated generator that is implanted in the left chest wall. Stimulation is directional (going to the brain), minimizing potential side effects from the VN's efferent projections. Stimulus parameters (e.g., stimulus intensity, frequency, and duration) can be programed by a physician to maximize efficacy. More recently, a non-surgical method of VNS known as transcutaneous VNS (t-VNS) has been developed, in which the auricular branch of the $\mathrm{VN}$ is stimulated by electrodes placed on the outer ear (17-19). This stimulation site is in close proximity to an acupuncture site that may stimulate the $\mathrm{VN}$ in a similar manner (20). Interestingly, a number of studies have shown poor parasympathetic regulation of autonomic function in schizophrenia (21-26), suggesting that hypoactive $\mathrm{VN}$ function may contribute to disease pathophysiology.

By using VNS in combination with various functional neuroimaging techniques, researchers have frequently examined how VNS affects human brain activity. One of the most consistent neurophysiological effects of VNS is decreased hippocampal activity, possibly through enhancement of GABAergic signaling (27). As shown in Table 1, decreased hippocampal activity after VNS has been reported in over 15 studies $(18,28-44)$, although some others have not reported significant effects $(45,46)$. Remarkably, this effect has been observed in epileptic patients, depressed patients, and healthy subjects, suggesting that VNS may decrease hippocampal activity independent of the pathological state of the subject. Most relevant to schizophrenia, a recent in vivo electrophysiology study using the methylazoxymethanol acetate (MAM) rodent model of schizophrenia found decreased hippocampal hyperactivity in rats after 2 weeks VNS treatment (44). Furthermore, deep brain stimulationinduced reduction of hippocampal hyperactivity improves cognitive flexibility in the MAM rat model (47), suggesting that hyperactivity of the region may be targeted to improve cognition in schizophrenia.

Vagus nerve stimulation also has demonstrated pro-cognitive effects in a number of studies. As reviewed by Vonck et al. (48), improved cognition after VNS has been observed in patients with epilepsy, Alzheimer's, and depression. Cognitive domains that have shown improvement include verbal recognition, attention, memory consolidation, and executive function (48). Other studies, however, have not shown significant effects, possibly due to changes in stimulus or study parameters (e.g., placebo design) (48). Indeed, studies 
Table 1 | Studies that have demonstrated effects of VNS on hippocampal activity

\begin{tabular}{|c|c|c|c|c|}
\hline $\begin{array}{l}\text { Subject } \\
\text { population }\end{array}$ & $\begin{array}{l}\text { VNS } \\
\text { method }\end{array}$ & $\begin{array}{l}\text { Imaging } \\
\text { technique }\end{array}$ & $\begin{array}{l}\text { Effect on HC } \\
\text { rBF/activity }\end{array}$ & Reference \\
\hline \multirow[t]{9}{*}{ Epilepsy } & $\mathrm{s}-\mathrm{VNS}$ & PET & $\downarrow$ & Henry et al. (28) \\
\hline & & PET & $\downarrow$ & Henry et al. (29) \\
\hline & & $\begin{array}{l}\text { HC depth } \\
\text { electrodes }\end{array}$ & $\begin{array}{c}\downarrow \text { (epileptiform } \\
\text { sharp waves) }\end{array}$ & Olejniczak et al. (33) \\
\hline & & SPECT & $\downarrow$ & Vonck et al. (31) \\
\hline & & SPECT & $\downarrow$ & Van Laere et al. (30) \\
\hline & & SPECT & $\downarrow$ & Van Laere et al. (34) \\
\hline & & SPECT & $\downarrow$ & Barnes et al. (35) \\
\hline & & PET & $\downarrow$ & Henry et al. (36) \\
\hline & & SPECT & $\downarrow$ & Vonck et al. (41) \\
\hline \multirow[t]{5}{*}{ Depression } & $\mathrm{s}-\mathrm{VNS}$ & SPECT & $\downarrow$ & Devous (32) \\
\hline & & fMRI & $\downarrow$ & Mu et al. (37) \\
\hline & & SPECT & $\downarrow$ & Zobel et al. (39) \\
\hline & & PET & n.s. & Pardo et al. (45) \\
\hline & & PET & n.s. & Conway et al. (46) \\
\hline \multirow[t]{3}{*}{ Healthy } & $t-V N S$ & fMRI & $\downarrow$ & Kraus et al. (40) \\
\hline & & $\mathrm{fMRI}$ & $\downarrow$ & Kraus et al. (42) \\
\hline & & fMRI & $\downarrow$ & Frangos et al. (43) \\
\hline \multirow[t]{2}{*}{ Animal (rat) } & $\mathrm{s}-\mathrm{VNS}$ & PET & $\downarrow$ & Dedeurwaerdere et al. (38) \\
\hline & & in vivo electrophysiology & $\downarrow$ & Perez et al. (44) \\
\hline
\end{tabular}

fMRI, functional magnetic resonance imaging; HC, hippocampus; n.s., no significant effects; PET, positron emission tomography; rBF, regional blood flow; s-VNS, surgicalVNS; SPECT, single-photon emission computed tomography; t-VNS, transcutaneous (non-surgical) VNS.

that examine the effects of chronic VNS often lack appropriate placebo controls due to ethical issues in applying "placebo" stimulation protocols to patient populations. This concern may be addressed by studies in healthy subjects using non-invasive $\mathrm{t}-\mathrm{VNS}$, in which placebo "stimulation" is delivered by an electrode placed on the earlobe (27). Nonetheless, the effects of noninvasive $\mathrm{t}$-VNS on cognitive performance have yet to be well evaluated.

The effects of VNS on neurotransmitter systems show important parallels with current lines of therapeutic investigation in schizophrenia. Ascending projections of the $\mathrm{VN}$ terminate in the nucleus tractus solitarius in the medulla, which in turn innervates the locus coeruleus and induces the release of norepinephrine (NE) (49, 50). Activation of adrenergic receptors in the hippocampus can thereby reduce the excitability of the region (51-53). In line with a role for increased adrenergic signaling in the treatment of schizophrenia, adrenergic $\alpha 2$ receptor agonists such as clonidine are currently being investigated in early phase trials in patients. Preliminary studies have demonstrated that activation of this receptor improves sensorimotor (54) and auditory gating (55) deficits in the disease. Guanfacine, an $\alpha 2 \mathrm{~A}$ receptor-specific agonist, also shows procognitive effects in several patient populations including schizophrenia (56-58).

A secondary effect of VNS directly relevant to schizophrenia is to increase cholinergic neurotransmission by NE-induced activation of postsynaptic beta and $\alpha 1$ adrenergic receptors in the basal forebrain, leading to increased acetylcholine (ACh) release (59). This increase may help normalize deficits in cholinergic neurotransmission in the disorder driven in large part by a significant reduction in the expression of nicotinic ACh receptors on inhibitory interneurons $(11,12$, 60-63). Loss of these receptors is also hypothesized to contribute to hippocampal hyperactivity $(10,11,62)$, which may be normalized by nicotinic activation of receptors on inhibitory interneurons (61, 64). In support of this view, nicotine, a nicotinic receptor agonist, reduces hippocampal hyperactivity observed during smooth pursuit eye movement in schizophrenia patients $(65,66)$. This attempt to "self-medicate" may help explain why the majority of patients smoke cigarettes (67). VNS may be a particularly effective method of potentiating nicotinic signaling as its cholinergic effects are conveyed via increased release of ACh. Relative to other nicotinic agonists (such as nicotine), $\mathrm{ACh}$ is more quickly degraded by endogenous enzymes, and is therefore less likely to induce receptor desensitization (68).

A third mechanism by which VNS may affect the neurobiology of schizophrenia is via its ability to increase serotonin release (69). Increased serotonergic tone may in turn decrease hippocampal hyperexcitability by potentiating GABAergic signaling through activation of several serotonin receptor subtypes, including 5HT-2, 3, and 4 (70-73). Activation of the 5 -HT1 serotonin receptor subtype is also associated with hippocampal neurogenesis and has been proposed as a potential mechanism to restore pattern separation (a memory-related hippocampal function) deficits in schizophrenia (74). Furthermore, activation of 5-HT3 receptors may relieve tonic inhibition of ACh release (75), increasing cholinergic tone and restoring hippocampal nicotinic signaling in the illness. How VNS specifically affects activity at these receptor targets and their relationship to cognition and hippocampal activity are important areas for future research.

Vagus nerve stimulation, whether administered by surgical implant or transcutaneous stimulation, is a well-tolerated procedure. Risks associated with the surgery itself are minimal (76). The most common side effects associated with stimulation are hoarseness, dyspnea, and cough. Most of these effects decrease with time (77). Nonetheless, VNS may have more significant risks specific to schizophrenia. Compounds that non-specifically (across all adrenergic receptor subtypes) increase noradrenergic activity, such as amphetamine, are known to induce psychosis in normal subjects $(78,79)$ and worsen positive symptoms in patients (80). Indeed, VNS itself has been associated with the onset of psychosis in epileptic patients in a limited number of case studies (81). It is possible that schizophrenia patients who are taking antipsychotic medication that participate in a VNS study will require 
adjustment of antipsychotic doses in order to preserve clinical efficacy. Previous studies, however, have also observed positive correlations between VN/parasympathetic nervous system dysfunction and positive symptoms, suggesting that VNS may actually improve these symptoms $(24,25)$. As the interactions between VNS and antipsychotic efficacy in schizophrenia are entirely unknown, studies should make closely monitor core symptoms of the illness associated with acute and chronic VNS treatment.

Despite its potential to improve cognition in schizophrenia, to our knowledge no study has yet examined the clinical or physiological effects of VNS in patients with the disease. Lack of research in this area may be due in large part to the invasiveness of traditional, surgical VNS. To that end, the advent of $\mathrm{t}$-VNS provides a simple, non-invasive method for examining the acute and chronic effects of stimulation in schizophrenia under various stimulus protocols. The recent discovery of hippocampal hyperactivity as a biomarker for cognitive symptoms in schizophrenia provides a useful mechanism to establish target validation using functional neuroimaging. In regards to VNS, the fact that numerous studies have repeatedly demonstrated that stimulation reduces hippocampal activity in other patient populations suggests that it may have the same effect in schizophrenia. Furthermore, although this article has focused on hippocampal effects, VNS may also improve cognition through other mechanisms, such as neurochemical modulation of the prefrontal cortex (8284) and/or prefrontal-hippocampal interactions (85). In summary, examination of the potential effects of VNS for cognitive symptoms in schizophrenia may be a promising future research direction.

\section{ACKNOWLEDGMENT}

JS is supported in part by National Institutes of Health Fellowship \#1F31MH102879-01A1. JT is supported in part by the Brain and Behavior Foundation, the Blowitz-Ridgeway Foundation, VA Grant \#5-I01-CX000459, and NIH Grants \#R01-DK089095, R21-DK10205201A1, and R01-MH102224-01A1.

\section{REFERENCES}

1. Green MF. What are the functional consequences of neurocognitive deficits in schizophrenia? Am
J Psychiatry (1996) 153:321-30. doi:10.1176/ajp. 153.3.321

2. Green MF, Nuechterlein KH, Gold JM, Barch DM, Cohen J, Essock S, et al. Approaching a consensus cognitive battery for clinical trials in schizophrenia: the NIMH-MATRICS conference to select cognitive domains and test criteria. Biol Psychiatry (2004) 56:301-7. doi:10.1016/j.biopsych.2004. 06.023

3. Torrey EF. Surviving Schizophrenia: A Manual for Families, Patients, and Providers. 5th ed. New York, NY: Harper Collins (2006).

4. Tregellas JR, Smucny J, Harris JG, Olincy A, Maharajh K, Kronberg E, et al. Intrinsic hippocampal activity as a biomarker for cognition and symptoms in schizophrenia. Am J Psychiatry (2014) 171:549-56. doi:10.1176/appi.ajp.2013.13070981

5. Scheef L, Manka C, Daamen M, Kuhn KU, Maier W, Schild HH, et al. Resting-state perfusion in nonmedicated schizophrenic patients: a continuous arterial spin-labeling 3.0-T MR study. Radiology (2010) 256:253-60. doi:10.1148/radiol.10091224

6. Schobel SA, Lewandowski NM, Corcoran CM, Moore H, Brown T, Malaspina D, et al. Differential targeting of the CA1 subfield of the hippocampal formation by schizophrenia and related psychotic disorders. Arch Gen Psychiatry (2009) 66:938-46. doi:10.1001/archgenpsychiatry.2009.115

7. Schobel SA, Chaudhury NH, Khan UA, Paniagua B, Styner MA, Asllani I, et al. Imaging patients with psychosis and a mouse model establishes a spreading pattern of hippocampal dysfunction and implicates glutamate as a driver. Neuron (2013) 78:81-93. doi:10.1016/j.neuron.2013.02.011

8. Tregellas JR, Davalos DB, Rojas DC, Waldo MC, Gibson L, Wylie K, et al. Increased hemodynamic response in the hippocampus, thalamus and prefrontal cortex during abnormal sensory gating in schizophrenia. Schizophr Res (2007) 92:262-72. doi:10.1016/j.schres.2006.12.033

9. Tregellas JR, Ellis J, Shatti S, Du YP, Rojas DC. Increased hippocampal, thalamic, and prefrontal hemodynamic response to an urban noise stimulus in schizophrenia. Am J Psychiatry (2009) 166:354-60. doi:10.1176/appi.ajp.2008.08030411

10. Tregellas JR. Neuroimaging biomarkers for early drug development in schizophrenia. Biol Psychiatry (2014) 76:111-9. doi:10.1016/j.biopsych.2013. 08.025

11. Miwa JM, Freedman R, Lester HA. Neural systems governed by nicotinic acetylcholine receptors: emerging hypotheses. Neuron (2011) 70:20-33. doi:10.1016/j.neuron.2011.03.014

12. Olincy A, Freedman R. Nicotinic mechanisms in the treatment of psychotic disorders: a focus on the alpha7 nicotinic receptor. Handb Exp Pharmacol (2012) 213:211-32. doi:10.1007/978-3642-25758-2_8

13. Yakel JL. Nicotinic ACh receptors in the hippocampus: role in excitability and plasticity. Nicotine Tob Res (2012) 14:1249-57. doi:10.1093/ntr/nts091

14. Heckers S, Konradi C. GABAergic mechanisms of hippocampal hyperactivity in schizophrenia. Schizophr Res (2014). doi:10.1016/j.schres.2014. 09.041

15. George MS, Aston-Jones G. Noninvasive techniques for probing neurocircuitry and treating illness: vagus nerve stimulation (VNS), transcranial magnetic stimulation (TMS) and transcranial direct current stimulation (tDCS). Neuropsychopharmacology (2010) 35:301-16. doi:10.1038/ npp. 2009.87

16. George MS, Sackeim HA, Rush AJ, Marangell LB, Nahas Z, Husain MM, et al. Vagus nerve stimulation: a new tool for brain research and therapy. Biol Psychiatry (2000) 47:287-95. doi:10.1016/ S0006-3223(99)00308-X

17. Ventureyra EC. Transcutaneous vagus nerve stimulation for partial onset seizure therapy. A new concept. Childs Nerv Syst (2000) 16:101-2. doi:10. 1007/s003810050021

18. Rong PJ, Fang JL, Wang LP, Meng H, Liu J, Ma YG, et al. Transcutaneous vagus nerve stimulation for the treatment of depression: a study protocol for a double blinded randomized clinical trial. BMC Complement Altern Med (2012) 12:255. doi:10.1186/1472-6882-12-255

19. Stefan H, Kreiselmeyer G, Kerling F, Kurzbuch K, Rauch C, Heers M, et al. Transcutaneous vagus nerve stimulation ( $\mathrm{t}$-VNS) in pharmacoresistant epilepsies: a proof of concept trial. Epilepsia (2012) 53:e115-8. doi:10.1111/j.1528-1167.2012.03492.x

20. He W, Wang X, Shi H, Shang H, Li L, Jing X, et al. Auricular acupuncture and vagal regulation. Evid Based Complement Alternat Med (2012) 2012:786839. doi:10.1155/2012/786839

21. Malaspina D, Bruder G, Dalack GW, Storer S, Van Kammen M, Amador X, et al. Diminished cardiac vagal tone in schizophrenia: associations to brain laterality and age of onset. Biol Psychiatry (1997) 41:612-7. doi:10.1016/S0006-3223(96)00161-8

22. Bar KJ, Letzsch A, Jochum T, Wagner G, Greiner $\mathrm{W}$, Sauer $\mathrm{H}$. Loss of efferent vagal activity in acute schizophrenia. J Psychiatr Res (2005) 39:519-27. doi:10.1016/j.jpsychires.2004.12.007

23. Boettger S, Hoyer D, Falkenhahn K, Kaatz M, Yeragani VK, Bar KJ. Altered diurnal autonomic variation and reduced vagal information flow in acute schizophrenia. Clin Neurophysiol (2006) 117:2715-22. doi:10.1016/j.clinph.2006.08.009

24. Bar KJ, Wernich K, Boettger S, Cordes J, Boettger MK, Loffler S, et al. Relationship between cardiovagal modulation and psychotic state in patients with paranoid schizophrenia. Psychiatry Res (2008) 157:255-7. doi:10.1016/j.psychres. 2007.04.021

25. Bar KJ, Rachow T, Schulz S, Bassarab K, Haufe $\mathrm{S}$, Berger S, et al. The phrenic component of acute schizophrenia - a name and its physiological reality. PLoS One (2012) 7:e33459. doi:10.1371/ journal.pone.0033459

26. Ostermann S, Herbsleb M, Schulz S, Donath L, Berger S, Eisentrager D, et al. Exercise reveals the interrelation of physical fitness, inflammatory response, psychopathology, and autonomic function in patients with schizophrenia. Schizophr Bull (2013) 39:1139-49. doi:10.1093/schbul/sbs085

27. Capone F, Assenza G, Di Pino G, Musumeci G, Ranieri F, Florio L, et al. The effect of transcutaneous vagus nerve stimulation on cortical excitability. J Neural Transm (2014). doi:10.1007/ s00702-014-1299-7

28. Henry TR, Bakay RA, Votaw JR, Pennell PB, Epstein CM, Faber TL, et al. Brain blood flow alterations induced by therapeutic vagus nerve stimulation in partial epilepsy: I. Acute effects at high and low levels of stimulation. Epilepsia (1998) 39:983-90. doi:10.1111/j.1528-1157.1998.tb01448.x 
29. Henry TR, Votaw JR, Pennell PB, Epstein CM, Bakay RA, Faber TL, et al. Acute blood flow changes and efficacy of vagus nerve stimulation in partial epilepsy. Neurology (1999) 52:1166-73. doi:10. 1212/WNL.52.6.1166

30. Van Laere K, Vonck K, Boon P, Brans B, Vandekerckhove T, Dierckx R. Vagus nerve stimulation in refractory epilepsy: SPECT activation study. J Nucl Med (2000) 41:1145-54.

31. Vonck K, Boon P, Van Laere K, D’Have M, Vandekerckhove T, O'Connor S, et al. Acute single photon emission computed tomographic study of vagus nerve stimulation in refractory epilepsy. Epilepsia (2000) 41:601-9. doi:10.1111/j.1528-1157.2000. tb00215.x

32. Devous M. Effects of VNS on regional cerebral blood flow in depressed subjects. In Vagus Nerve Stimulation (VNS) for Treatment-Resistant Depression Satellite Symposium in Conjunction with the 7th World Congress of Biological Psychiatry). Berlin (2001).

33. Olejniczak PW, Fisch BJ, Carey M, Butterbaugh G, Happel L, Tardo C. The effect of vagus nerve stimulation on epileptiform activity recorded from hippocampal depth electrodes. Epilepsia (2001) 42:423-9. doi:10.1046/j.1528-1157.2001.10900.x

34. Van Laere K, Vonck K, Boon P, Versijpt J, Dierckx R. Perfusion SPECT changes after acute and chronic vagus nerve stimulation in relation to prestimulus condition and long-term clinical efficacy. $\mathrm{J} \mathrm{Nucl}$ Med (2002) 43:733-44.

35. Barnes A, Duncan R, Chisholm JA, Lindsay K, Patterson J, Wyper D. Investigation into the mechanisms of vagus nerve stimulation for the treatment of intractable epilepsy, using 99mTc-HMPAO SPET brain images. Eur J Nucl Med Mol Imaging (2003) 30:301-5. doi:10.1007/s00259-002-1026-8

36. Henry TR, Bakay RA, Pennell PB, Epstein CM, Votaw JR. Brain blood-flow alterations induced by therapeutic vagus nerve stimulation in partial epilepsy: II. prolonged effects at high and low levels of stimulation. Epilepsia (2004) 45:1064-70. doi:10.1111/j.0013-9580.2004.03104.x

37. Mu Q, Bohning DE, Nahas Z, Walker J, Anderson $\mathrm{B}$, Johnson KA, et al. Acute vagus nerve stimulation using different pulse widths produces varying brain effects. Biol Psychiatry (2004) 55:816-25. doi:10.1016/j.biopsych.2003.12.004

38. Dedeurwaerdere S, Cornelissen B, Van Laere K, Vonck K, Achten E, Slegers G, et al. Small animal positron emission tomography during vagus nerve stimulation in rats: a pilot study. Epilepsy Res (2005) 67:133-41. doi:10.1016/j.eplepsyres.2005. 09.008

39. Zobel A, Joe A, Freymann N, Clusmann H, Schramm J, Reinhardt $M$, et al. Changes in regional cerebral blood flow by therapeutic vagus nerve stimulation in depression: an exploratory approach. Psychiatry Res (2005) 139:165-79. doi: 10.1016/j.pscychresns.2005.02.010

40. Kraus T, Hosl K, Kiess O, Schanze A, Kornhuber J, Forster C. BOLD fMRI deactivation of limbic and temporal brain structures and mood enhancing effect by transcutaneous vagus nerve stimulation. J Neural Transm (2007) 114:1485-93. doi:10.1007/s00702-007-0755-Z

41. Vonck K, De Herdt V, Bosman T, Dedeurwaerdere S, Van Laere K, Boon P. Thalamic and limbic involvement in the mechanism of action of vagus nerve stimulation, a SPECT study. Seizure (2008) 17:699-706. doi:10.1016/j.seizure.2008.05.001

42. Kraus T, Kiess O, Hosl K, Terekhin P, Kornhuber J, Forster C. CNS BOLD fMRI effects of sham-controlled transcutaneous electrical nerve stimulation in the left outer auditory canal - a pilot study. Brain Stimul (2013) 6:798-804. doi:10.1016/ j.brs.2013.01.011

43. Frangos E, Ellrich J, Komisaruk BR. Non-invasive access to the vagus nerve central projections via electrical stimulation of the external ear: fMRI evidence in humans. Brain Stimul (2014). doi:10. 1016/j.brs.2014.11.018

44. Perez SM, Carreno FR, Frazer A, Lodge DJ. Vagal nerve stimulation reverses aberrant dopamine system function in the methylazoxymethanol acetate rodent model of schizophrenia. J Neurosci (2014) 34:9261-7. doi:10.1523/JNEUROSCI. 0588-14.2014

45. Pardo JV, Sheikh SA, Schwindt GC, Lee JT, Kuskowski MA, Surerus C, et al. Chronic vagus nerve stimulation for treatment-resistant depression decreases resting ventromedial prefrontal glucose metabolism. Neuroimage (2008) 42:879-89. doi:10.1016/j.neuroimage.2008.04.267

46. Conway CR, Sheline YI, Chibnall JT, Bucholz RD, Price JL, Gangwani S, et al. Brain bloodflow change with acute vagus nerve stimulation in treatment-refractory major depressive disorder. Brain Stimul (2012) 5:163-71. doi:10.1016/j.brs. 2011.03.001

47. Perez SM, Shah A, Asher A, Lodge DJ. Hippocampal deep brain stimulation reverses physiological and behavioural deficits in a rodent model of schizophrenia. Int J Neuropsychopharmacol (2013) 16:1331-9. doi:10.1017/S1461145712001344

48. Vonck K, Raedt R, Naulaerts J, De Vogelaere F, Thiery E, Van Roost D, et al. Vagus nerve stimulation.25 years later! What do we know about the effects on cognition? Neurosci Biobehav Rev (2014) 45:63-71. doi:10.1016/j.neubiorev.2014.05.005

49. Van Bockstaele EJ, Peoples J, Telegan P. Efferent projections of the nucleus of the solitary tract to peri-locus coeruleus dendrites in rat brain: evidence for a monosynaptic pathway. J Comp Neurol (1999) 412:410-28. doi:10.1002/(SICI) 1096-9861(19990927)412:3<410::AID-CNE3>3. $0 . \mathrm{CO} ; 2-\mathrm{F}$

50. Van Bockstaele EJ, Peoples J, Valentino RJ. A.E. Bennett research award. Anatomic basis for differential regulation of the rostrolateral peri-locus coeruleus region by limbic afferents. Biol Psychiatry (1999) 46:1352-63. doi:10.1016/S0006-3223(99) 00213-9

51. Jurgens CW, Hammad HM, Lichter JA, Boese SJ, Nelson BW, Goldenstein BL, et al. Alpha2A adrenergic receptor activation inhibits epileptiform activity in the rat hippocampal CA3 region. Mol Pharmacol (2007) 71:1572-81. doi:10.1124/ mol.106.031773

52. Hillman KL, Lei S, Doze VA, Porter JE. Alpha-1A adrenergic receptor activation increases inhibitory tone in CA1 hippocampus. Epilepsy Res (2009) 84:97-109. doi:10.1016/j.eplepsyres.2008.12.007

53. Lipski WJ, Grace AA. Activation and inhibition of neurons in the hippocampal ventral subiculum by norepinephrine and locus coeruleus stimulation.
Neuropsychopharmacology (2013) 38:285-92. doi: 10.1038/npp.2012.157

54. Oranje B, Glenthoj BY. Clonidine normalizes sensorimotor gating deficits in patients with schizophrenia on stable medication. Schizophr Bull (2013) 39:684-91. doi:10.1093/schbul/ sbs071

55. Oranje B, Glenthoj BY. Clonidine normalizes levels of $\mathrm{P} 50$ gating in patients with schizophrenia on stable medication. Schizophr Bull (2014) 40:1022-9. doi:10.1093/schbul/sbt144

56. Friedman JI, Adler DN, Temporini HD, Kemether E, Harvey PD, White L, et al. Guanfacine treatment of cognitive impairment in schizophrenia. Neuropsychopharmacology (2001) 25:402-9. doi: 10.1016/S0893-133X(01)00249-4

57. Ruggiero S, Clavenna A, Reale L, Capuano A, Rossi F, Bonati M. Guanfacine for attention deficit and hyperactivity disorder in pediatrics: a systematic review and meta-analysis. Eur Neuropsychopharmacol (2014) 24:1578-90. doi:10.1016/j. euroneuro.2014.08.001

58. Fox H, Sofuoglu M, Sinha R. Guanfacine enhances inhibitory control and attentional shifting in early abstinent cocaine-dependent individuals. J Psychopharmacol (2015) 29(3):312-23. doi:10.1177/ 0269881114562464

59. Fort P, Khateb A, Pegna A, Muhlethaler M, Jones BE. Noradrenergic modulation of cholinergic nucleus basalis neurons demonstrated by in vitro pharmacological and immunohistochemical evidence in the guinea-pig brain. Eur J Neurosci (1995) 7:1502-11. doi:10.1111/j.1460-9568.1995. tb01145.x

60. Freedman R, Hall M, Adler LE, Leonard S. Evidence in postmortem brain tissue for decreased numbers of hippocampal nicotinic receptors in schizophrenia. Biol Psychiatry (1995) 38:22-33. doi:10.1016/0006-3223(94)00252-X

61. Frazier CJ, Rollins YD, Breese CR, Leonard S, Freedman R, Dunwiddie TV. Acetylcholine activates an alpha-bungarotoxin-sensitive nicotinic current in rat hippocampal interneurons, but not pyramidal cells. J Neurosci (1998) 18:1187-95.

62. Freedman R, Adams CE, Leonard S. The alpha7nicotinic acetylcholine receptor and the pathology of hippocampal interneurons in schizophrenia. $J$ Chem Neuroanat (2000) 20:299-306. doi:10.1016/ S0891-0618(00)00109-5

63. Leonard S, Breese C, Adams C, Benhammou K, Gault J, Stevens K, et al. Smoking and schizophrenia: abnormal nicotinic receptor expression. Eur J Pharmacol (2000) 393:237-42. doi:10.1016/ S0014-2999(00)00035-2

64. Szabo GG, Holderith N, Gulyas AI, Freund TF, Hajos N. Distinct synaptic properties of perisomatic inhibitory cell types and their different modulation by cholinergic receptor activation in the $\mathrm{CA} 3$ region of the mouse hippocampus. Eur J Neurosci (2010) 31:2234-46. doi:10.1111/j.1460-9568. 2010.07292.x

65. Tregellas JR, Tanabe JL, Martin LF, Freedman R. FMRI of response to nicotine during a smooth pursuit eye movement task in schizophrenia. Am J Psychiatry (2005) 162:391-3. doi:10.1176/appi. ajp.162.2.391

66. Tanabe J, Tregellas JR, Martin LF, Freedman R. Effects of nicotine on hippocampal and cingulate 
activity during smooth pursuit eye movement in schizophrenia. Biol Psychiatry (2006) 59:754-61. doi:10.1016/j.biopsych.2005.09.004

67. Winterer G. Why do patients with schizophrenia smoke? Curr Opin Psychiatry (2010) 23:112-9. doi:10.1097/YCO.0b013e3283366643

68. Papke RL. Merging old and new perspectives on nicotinic acetylcholine receptors. Biochem Pharmacol (2014) 89:1-11. doi:10.1016/j.bcp. 2014.01.029

69. Dorr AE, Debonnel G. Effect of vagus nerve stimulation on serotonergic and noradrenergic transmission. J Pharmacol Exp Ther (2006) 318:890-8. doi:10.1124/jpet.106.104166

70. Ropert N, Guy N. Serotonin facilitates GABAergic transmission in the CAl region of rat hippocampus in vitro. J Physiol (1991) 441:121-36. doi:10.1113/jphysiol.1991.sp018742

71. Shen RY, Andrade R. 5-Hydroxytryptamine2 receptor facilitates GABAergic neurotransmission in rat hippocampus. J Pharmacol Exp Ther (1998) 285:805-12.

72. Marchetti E, Chaillan FA, Dumuis A, Bockaert J, Soumireu-Mourat B, Roman FS. Modulation of memory processes and cellular excitability in the dentate gyrus of freely moving rats by a 5-HT4 receptors partial agonist, and an antagonist. $\mathrm{Neu}$ ropharmacology (2004) 47:1021-35. doi:10.1016/j. neuropharm.2004.06.033

73. Choi IS, Cho JH, Kim JT, Park EJ, Lee MG, Shin $\mathrm{HI}$, et al. Serotoninergic modulation of GABAergic synaptic transmission in developing rat CA3 pyramidal neurons. J Neurochem (2007) 103:2342-53. doi:10.1111/j.1471-4159.2007.04945.x

74. Schreiber R, Newman-Tancredi A. Improving cognition in schizophrenia with antipsychotics that elicit neurogenesis through 5-HT(1A) receptor activation. Neurobiol Learn Mem (2014) 110:72-80. doi:10.1016/j.nlm.2013.12.015
75. Shirazi-Southall S, Rodriguez DE, Nomikos GG. Effects of typical and atypical antipsychotics and receptor selective compounds on acetylcholine efflux in the hippocampus of the rat. Neuropsychopharmacology (2002) 26:583-94. doi: 10.1016/S0893-133X(01)00400-6

76. O'Reardon JP, Cristancho P, Peshek AD. Vagus nerve stimulation (VNS) and treatment of depression: to the brainstem and beyond. Psychiatry (Edgmont) (2006) 3:54-63.

77. Sackeim HA, Rush AJ, George MS, Marangell LB, Husain MM, Nahas Z, et al. Vagus nerve stimulation (VNS) for treatment-resistant depression: efficacy, side effects, and predictors of outcome. Neuropsychopharmacology (2001) 25:713-28. doi:10.1016/S0893-133X(01) 00271-8

78. Angrist B, Corwin J, Bartlik B, Cooper T. Early pharmacokinetics and clinical effects of oral Damphetamine in normal subjects. Biol Psychiatry (1987) 22:1357-68. doi:10.1016/0006-3223(87) 90070-9

79. Grant KM, Levan TD, Wells SM, Li M, Stoltenberg SF, Gendelman HE, et al. Methamphetamineassociated psychosis. J Neuroimmune Pharmacol (2012) 7:113-39. doi:10.1007/s11481-011-9288-1

80. Curran C, Byrappa N, Mcbride A. Stimulant psychosis: systematic review. Br J Psychiatry (2004) 185:196-204. doi:10.1192/bjp.185.3.196

81. De Herdt V, Boon P, Vonck K, Goossens L, Nieuwenhuis L, Paemeleire K, et al. Are psychotic symptoms related to vagus nerve stimulation in epilepsy patients? Acta Neurol Belg (2003) 103:170-5.

82. Briand LA, Gritton H, Howe WM, Young DA, Sarter M. Modulators in concert for cognition: modulator interactions in the prefrontal cortex. Prog Neurobiol (2007) 83:69-91. doi:10.1016/j. pneurobio.2007.06.007
83. Potkin SG, Turner JA, Brown GG, Mccarthy G, Greve DN, Glover GH, et al. Working memory and DLPFC inefficiency in schizophrenia: the FBIRN study. Schizophr Bull (2009) 35:19-31. doi:10. 1093/schbul/sbn 162

84. Sumiyoshi T, Higuchi Y, Uehara T. Neural basis for the ability of atypical antipsychotic drugs to improve cognition in schizophrenia. Front Behav Neurosci (2013) 7:140. doi:10.3389/fnbeh.2013. 00140

85. Sigurdsson T, Stark KL, Karayiorgou M, Gogos JA, Gordon JA. Impaired hippocampal-prefrontal synchrony in a genetic mouse model of schizophrenia. Nature (2010) 464:763-7. doi:10.1038/ nature 08855

Conflict of Interest Statement: The authors declare that the research was conducted in the absence of any commercial or financial relationships that could be construed as a potential conflict of interest.

Received: 21 January 2015; accepted: 10 March 2015; published online: 24 March 2015.

Citation: Smucny J, Visani A and Tregellas JR (2015)

Could vagus nerve stimulation target hippocampal hyperactivity to improve cognition in schizophrenia? Front. Psychiatry 6:43. doi: 10.3389/fpsyt.2015.00043

This article was submitted to Neuropsychiatric Imaging and Stimulation, a section of the journal Frontiers in Psychiatry.

Copyright (c) 2015 Smucny, Visani and Tregellas. This is an open-access article distributed under the terms of the Creative Commons Attribution License (CC BY). The use, distribution or reproduction in other forums is permitted, provided the original author(s) or licensor are credited and that the original publication in this journal is cited, in accordance with accepted academic practice. No use, distribution or reproduction is permitted which does not comply with these terms. 